International Journal of Educational Review

Volume 3 Issue 2 (2021) Page 245-256

ISSN 2685-709X (Online) 2685-905X (Print)

\title{
Efforts of Islamic Religious Education Teachers in Improving Learning Outcomes in Aqidah Subjects of Grade VII Morals in MTs Al Furqon Klari Karawang
}

\author{
Ilyas Prasetyo ${ }^{(1)}$, Ajat Rukajat ${ }^{(2)}$, Sutarjo $^{(3)}$ \\ ${ }^{(1)}$ Universitas Singaperbangsa Karawang, Indonesia, (2),(3) Universitas \\ Singaperbangsa Karawang, Indonesia \\ Corresponding Author E-mail: 2010632030013@student.unsika.ac.id
}

Received 18 November 2021; Revised 18 December 2021; Accepted 26

December 2021

\begin{abstract}
This Akhlak Creed subject is a branch of Islamic religious education, the subject of moral faith in forming religious character emphasizes the aspect of habituation early on and not only the responsibility of the school but all participate in improving the learning outcomes of learners involving families, schools and community environments. The purpose of this study is to find out the efforts of PAI teachers in improving the learning outcomes of learners in moral faith subjects carried out in class VII at MTs Al-Furqon Klari Karawang. The subjects of the study were principals, PAI teachers and students. This research method is qualitatively descriptive i.e. written or oral of the research object. Data collection techniques use observations, interviews, and documentation. The result of PAI teacher efforts, learners in moral faith subjects there is an increase in terms of written value and skills.
\end{abstract}

Keywords: Akhlak Creed, Learners, Learning Outcomes. 


\section{Introduction}

Since man was born into the world, it has been equipped by Allah SWT with curiosity. The form of this curiosity is the existence of reason. With the human mind thinking so that he gets knowledge that will continue to grow. To realize the ability of reason, education is needed. Education is the most important thing in our lives, as Allah (SWT) commanded the Prophet Muhammad (peace be upon him) by the command of Iqra' (Read). In accordance with the word of Allah SWT:

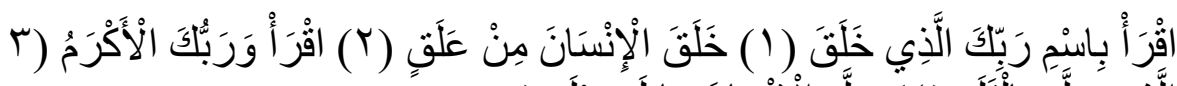

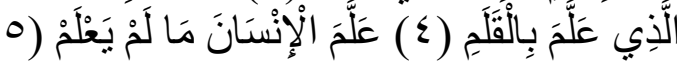

"Read by the name of your Lord who created, He created man from a lump of blood. Read it and your Lord is merciful. Who teaches (Man) through the intercession of Kalam." (QS. Al-Alaq 1-5).

The verse explains that Allah almighty is the creator of all things in this universe and has created man from a lump of blood through the process that has been established by Him. Allah declares Himself that $\mathrm{He}$ is the Most Merciful, so that he is not

To be shunned let alone feared. But you have to be approached by yourself. $\mathrm{He}$ is the wise Educator, educating man with science and by writing and reading. From the meaning of this verse we can conclude that, as beings who are able to receive education or beings who can be educated, demanding knowledge is essential to our survival in the world in the world.

Demanding knowledge is also an obligation, as mentioned in the hadith of the Prophet Muhammad (peace be upon him):

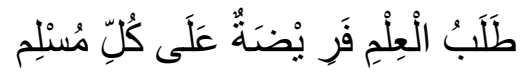

"Demanding knowledge is obligatory upon every Muslim" (HR. Ibnu Majah)

The hadith explains that every Muslim is obliged to study because knowledge is the key to all goodness and is a means to fulfill what Allah obliges us to do.

Studying is contained in education with teaching and learning activities. Teaching and learning activities are a condition that is deliberately created. It is the teacher who created it to teach the students. Teachers who teach and students 
who learn. The combination of the two elements was then born an educative interaction by utilizing the material as a medium. (Hardini, 2012:11).

In the process of education efforts or efforts of teachers are very important for the continuity of a good teaching and learning process and the need for a teaching and learning strategy. Strategy teaching and learning consists of all components of teaching materials and procedures that will be used to help students achieve certain teaching goals. In other words, teaching and learning strategies are also the selection of certain types of exercises that match the goals to be achieved. (Hamdani, 2011:19).

Teachers whofulfill the task of teaching will always be an agent oflearning, because as a learning agent, every teacher must have four kinds of competencies, as stated in the Law of the Republic of Indonesia No. 14 of 2005 article 10 (2009: 57), "Teacher competence includes: pedagogical competence, personality competence, social competence and professional competence obtained through professional education." Overall, these four types of competencies can sustain learning services by teachers to students to be better, so that on the one hand the teacher becomes a qualified teacher and on the other hand learners become strong learners. As kunandar (2009: 51) Professional teachers are believed to be able to deliver learners in learning to find, manage and combine their acquisition and solve problems related to knowledge, attitudes and values and life skills. Professional teachers are believed to be able to enable learners to think, behave and act creatively.

\section{Theoretical Foundation}

\section{A. Understanding of PAI Teacher}

According to Poerwadarminta $(2006: 291)$ it is stated that educators are people who educate. While educating itself means maintaining and providing practice on morals and intelligence of the mind.

According to Zakiah daradjat (1992: 39) as a general vocabulary, educators also include teachers, lecturers, and professors. The teacher is a professional educator, because he has implicitly relinquished himself to accept and assume some of the responsibilities of parents. And not just anyone can serve as a teacher.

According to Hadari Nawawi (1989: 123) said, etymologically or in a narrow sense the teacher is a person whose work teaches or gives lessons in school / 
classroom. More broadly, teachers mean people who work in education and teaching who are responsible for helping children reach their own maturity.

According to Mahmud (2010:289) the proper term to refer to the teacher is mu"allim. The original meaning of this word in Arabic is marking. Psychologically the teacher's job is to change the behavior of the student. Basically changing a student's behavior is a sign, i.e. a sign of change.

According to Syaiful Bahri Djamarah (2000:31-32) revealed, teachers are all people who are authorized and responsible for guiding and fostering students, both individually and classically, in school and outside school.

According to Mu"earif (2005:198-199) revealed, the teacher is a figure who becomes suri tauladan, the teacher is a figure who is gugu (trusted) and imitated (exemplified), educating in a harmonious way covered with affection. The teacher is a student's study friend who gives direction in the learning process, so the teacher figure is not a scary scourge for students.

So some understanding of teachers according to education experts. As for the understanding of Islamic Agam education itself researchers cite from several sources of books as follows:

According to Muhaimin (2012:123) PAI is standardized as the name of activities to educate Islam. PAI as a subject should be called "Religion of Islam", because what is taught is Islam, not Islamic religious education. The name of its activities or efforts in educating Islam is referred to as Islamic religious education. The word "education" is on and follows every subject. Islamic education is a part of Islamic education.

According to Muhammad Alim (2006: 06) that Islamic Religious Education can be interpreted as a planned program in preparing learners to know, understand, live, and follow guidance to respect the adherents of other religions in relation to harmony between religious people to realize unity and unity of the nation.

Based on R.I. Law No.20/ 2003 and Government Regulation R.I. No.19/2005 article 6 (1) religious education is intended to form learners into people who believe and fear God Almighty and be noble. Religious education (Islam) as a duty and obligation of the government in carrying out the aspirations of the people must reflect and lead towards the achievement of pancasila society with religious color. Religion and Pancasila must fill each other and support each other.

According to Wahab et al (2011:63) means Guru PAI is a teacher who teaches the subjects of Moral Faith, Qur'an and Hadith, Fiqh or History of Islamic 
Culture (SKI) in Madrasah. 16 This is in accordance with the Regulation of the Minister of Religious Affairs R.I. No.2/2008, that PAI subjects in madrasah Tsanawiyah consist of four subjects of Qur'an-Hadith, Creed-Akhlak, Jurisprudent, and History of Islamic Culture.

\section{B. PAI Teacher Duties and Functions}

There are many understandings expressed by education experts about Islamic religious education, in short the understanding of PAI teachers are teachers who teach the subjects of Moral Faith, Qur'an and Hadith, Fiqh or History of Islamic Culture (SKI) in schools / madrasas, the task of forming students into human beings of faith and fear to God Almighty, guide, educate and provide knowledge to students, experts in the material and how to teach the material, as well as being a suri tauladan for his students.

Islamic religious education is carried out to prepare learners to believe, understand and practice the teachings of Islam. Such education is through guidance, teaching, or training activities that have been determined to achieve the goals that have been set.

In Law No. 20 of 2003 on the National Education System, it is stated that:

National education serves to develop the ability and form the character and civilization of a dignified nation in order to educate

The life of the nation, aims to develop the potential of learners to become human beings who believe and fear God Almighty, be noble, healthy, knowledgeable, capable, creative, independent, and become democratic and responsible citizens.

To achieve this goal, one of the fields of study that must be studied by learners in madrassas is Islamic religious education, because religious education has a main mission in instilling the basic values of faith, worship and morals.

From some of the above opinions, it is clear that Islamic Religious Education aims to increase the belief, understanding, imagination and practice about the religion of Islam, so as to become a Muslim human being who believes, and fear Allah SWT. and be noble in personal life, society, nation and state.

Thus, a man who is highly capable in physical and spiritual life will become a society that can develop harmoniously in the physical and mental fields, both in the relationship between humans horizontally and vertically with the Creator. 
Human beings who achieve the goal of Islamic religious education will be able to enjoy happiness in the world and the hereafter.

\section{Results and Discussion}

\section{A. PAI Teacher's Efforts in Improving Learners' Learning Outcomes Class VII Akhlak Subjects at Madrasah Tsanawiyah Al Furqon Klari Karawang}

\section{Resation Method}

According to Djamarah and Zain (2006: 85) the method of assignment (recitation) "the method of presentation of materials, where the teacher gives certain tasks so that students do learning activities that can be done in the classroom, in the school yard, in the laboratory, in the library and in other supportive school environments".

PAI teachers' efforts in improving the learning outcomes of learners in class VII morals in madrasah tsanawiyah Al-Furqon Klari Karawang uses the method of "recitation" to support teaching and learning activities, so that it can be used as an effective tool to achieve teaching goals. Using this method is because of an outside class, thus making students more passionate in learning.

\section{Discussion}

According to Usman (2005) group discussion is an organized process that involves a group of people in informal face-to-face interactions with various experiences or information, inference or problem solving.

The advantage of this method of discussion is that the classroom atmosphere is livelier, because students direct their attention and mind to the issues being discussed can increase the achievement of individual personalities, such as tolerance, democracy, critical thinking, and patience.

Discussion is a way of learning and fun and stimulating experience is a way of releasing ideas and deepening insights about something. 


\section{Q\&A}

According to Drs. Soetomo (1993: 148) the Q\&A method is a method by which teachers use questions to students and students answer questions, or instead students ask teachers and teachers answer student questions.

One of them uses the Q\&A method so that in class is not monotonous; this Q\&A method can make students more active and can encourage student curiosity. Arouse students' interest and curiosity about the issues being talked about, develop students' active thinking and learning patterns and focus students' attention on the issues being discussed.

\section{B. Supporting Factors and Inhibiting PAI Teacher Efforts in improving Learners' Learning Outcomes in Akidah Subjects Class VII morals at Madrasah Tsanawiyah Al Furqon Klari Karawang}

\section{Supporting Factors}

\section{A. Principal}

In an effort to improve the quality of teachers, the Principal often delegates teachers including Aqidah Akhlak Subject Teachers to participate in training conducted by the Education Office and the Ministry of Religious Affairs, in the hope that after participating in the training, the Teacher has a new idea or idea that can be applied in the learning process which in the end by developing professional competencies can be influential in improving the quality of learning expected. It can also improve the learning outcomes or achievements of learners.

\section{B. PAI Teacher}

The second supporter is the teacher of his moral faith in the following way:

1. Create a learning plan.

2. Provide motivation to learners to be serious in taking lessons

3. Repeat the material that has been delivered.

4. Teachers always ask learners if there is material that is less understandable for learners.

5. Create a conducive and communicative learning atmosphere. 
6. Conduct an evaluation.

With the effort and competence carried out and owned by teachers of moral faith subjects, then in learning activities it is expected that there is relevant input or response from learners.

\section{Inhibitory Factors PAI Teacher Who Has a Dual Role}

Less optimal teacher can hamper the teaching and learning process because teachers have a dual role both as classroom guardians, laboratory in charge, head of the subject group or as a guide for learners in learning or as BK teachers. This shows the many responsibilities and duties of a teacher in improving the quality of learning in schools.

\section{Conclusion}

In an effort to improve the quality of teachers, the Principal often delegates teachers including Aqidah Akhlak Subject Teachers to participate in training conducted by the Education Office and the Ministry of Religious Affairs, in the hope that after participating in the training, the Teacher has a new idea or idea that can be applied in the learning process which in the end by developing professional competencies can be influential in improving the quality of learning expected. It can also improve the learning outcomes or achievements of learners.

Less optimal teacher can hamper the teaching and learning process because teachers have a dual role both as classroom guardians, laboratory in charge, head of the subject group or as a guide for learners in learning or as BK teachers. This shows the many responsibilities and duties of a teacher in improving the quality of learning in schools.

\section{Acknowledgement}

From the discussion of the results of research on pai teacher efforts in improving the learning outcomes of learners in class VII morals at MTS AlFurqon Karawang, it can be concluded as follows:

1. How are the efforts of PAI teachers in improving students' learning outcomes in class VII morals at MTS Al-Furqon Karawang?

PAI teachers' efforts in improving the learning outcomes of learners in class VII morals in madrasah tsanawiyah Al-furqon Klari Karawang uses the method of 
"recitation" to support teaching and learning activities, so that it can be used as an effective tool to achieve teaching goals. Using this method is because of an outside class, thus making students more passionate in learning.

The advantage of this method of discussion is that the classroom atmosphere is livelier, because students direct their attention and mind to the issues being discussed can increase the achievement of individual personalities, such as tolerance, democracy, critical thinking, and patience.

Discussion is a way of learning and fun and stimulating experience is a way of releasing ideas and deepening insights about something.

One of them uses the Q\&A method so that in class is not monotonous; this Q\&A method can make students more active and can encourage student curiosity. Arouse students' interest and curiosity about the issues being talked about, develop students' active thinking and learning patterns and focus students' attention on the issues being discussed.

2. What are the supporting factors and obstacles to pai teachers' efforts in improving learners' learning outcomes in class VII morals at MTS Al-Furqon Karawang?

In an effort to improve the quality of teachers, the Principal often delegates teachers including Aqidah Akhlak Subject Teachers to participate in training conducted by the Education Office and the Ministry of Religious Affairs, in the hope that after participating in the training, the Teacher has a new idea or idea that can be applied in the learning process which in the end by developing professional competencies can be influential in improving the quality of learning expected. It can also improve the learning outcomes or achievements of learners.

3. What is the result of PAI teachers' efforts in improving students' learning outcomes in class VII morals at MTS Al-Furqon Karawang?

The result of pai teacher's efforts in improving the learning outcomes of learners in the subjects of class VII morals in madrasah tsanawiyah al-furqon klari karawang that some students of class VII are able to improve the ability / value in the subjects of moral faith, although not all because the child's abilities are different.

According to researchers at MTs Al-Furqon from an early age has been instilled character education with before entering the prayer should be prayed dhuha jamaah in the mosque, continued after the prayer talaqi / preaching al253 
Qur'an and continued if it has entered the prayer time learning activities are rested and required for all teachers and students to follow the activities that have been approved, namely congregational prayer.

\section{References}

Ahsana Media 4, no. 2 (2018): 36-46.

Al-Ikhtibar: Journal of Educational Sciences Volume 7 No. 2, July-December 2020

Andriani, S., Kesumawati, N., \& Kristiawan, M. (2018). The Influence of the Transformational Leadership and Work Motivation on Teachers Performance. International Journal of Scientific \& Technology Research, 7(7).

Apriana, D., Kristiawan, M., \& Wardiah, D. (2019). Headmaster's Competency In Preparing Vocational School Students For Entrepreneurship. International Journal of Scientific \& Technology Research, 8(8).

Aziz, H. A. (2011). The character of the professional teacher gives birth to superior students answering the challenges of the future [The character of the professional teacher gives birth to superior students answering future challenges]. Jakarta: Al-Mawardi Prima.

Daryanto, Education Administration, (Jakarta: Rineka Cipta, 2001).

Donni Juni Priansa \& Rismi Somad, Supervised Management \& Principal Leadership,(Bandung: ALFABETA, 2014).

E. Mulyasa., 2005, Becomes a Professional Principal in the Context ofSucceeding MBS and KBK,cet. V, (Bandung: Rosda Karya, 2005).

Education." Ta'allum: Journal of Islamic Education 4, no. 1 (2016): 19-42.

Fahmi, M., Maulana, A., \& Yusuf, A. A. (2011). Teacher sertification in Indonesia; a confusion of means and ends. Bandung: CEDS Padjajaran University.

Fathurrohman, Muhammad. "The Development of Religious Culture in Improving Quality

Fawaid, Ahmad. "Reconstruction of the Role of Teachers Through the Values of the Qur'an in the Modern Era."

Fitria, H. (2018). The Influence Of Organizational Culture And Trust Through The Teacher Performance In The Private Secondary School In Palembang. International Journal of Scientific \& Technology Research, 7(7). 
Husaini Usman, Administration, Management, and Education Leadership,(Jakarta: PT bumi Aksara, 2019).

Husein, L. (2017). Teaching profession: becoming a professional teacher [Teaching profession: becoming a professional teacher]. Yogyakarta: New Library press.

Irmayani, H., Wardiah, D., \& Kristiawan, M. (2018). The Strategy of SD Pusri In Improving Educational Quality. International Journal of Scientific \& Technology Research, 7(7).

Islamic Legal Communication and Thought 9, no. 2 (April 29, 2018): 332-45. https://doi.org/10.30739/darussalam.v9i2.234.

Kristiawan, M. (2017). Education Management [Education Management]. Yogyakarta: Deepublish.

Kristiawan, M., Nizarani., \& Shamsidar. (2019). Role of School on Forming Character of Z-Generation Through Entrepreneurial Skills. International Journal of Scientific \& Technology Research, 8(10).

M, Print ISSN: 2338-4743, Online ISSN: 2477-2992

Michael Armstrong, Armstrong's Handbook of Management and leadership: A Guide to Managing for Result, (London: Kogan Page Limited, 2009).

Oemar Hamalik, Teaching and Learning Process,(Jakarta: Bumi Aksara, 2003).

Roesli, Mohammad, Ahmad Shafi'i, and Aina Amalia. "Islamic Studies on Parental Participation in Children's Education." Journal of Darussalam: Journal of Education,

Roulston, Kathryn. "Analysing Interviews." The SAGE Handbook of Qualitative Data Analysis, 2014, 297-312.

Sallis, E. (2006). Total quality management in education. Yogyakarta: IRCISod.

Salwa., Kristiawan, M., \& Lian, B. (2019). The Effect of Academic Qualification, Work Experience and Work Motivation towards Primary School Principal Performance. International Journal of Scientific \& Technology Research, 8(8).

Samae, Miss Saining, and S. Pd I. Istanto. "The Influence of Teacher's Example in Instilling The Moral Value of Students in Madrasah Tsanawiyah Negeri 2 Surakarta." PhD Thesis, University of Muhammadiyah Surakarta, 2017.

Satriadi. (2016). The influence of the principal's leadership on teacher performance. Benefita Journal Vol. 1 No. 3, 123-133.

Satrijo Budiwibowo \& Sudarmiani, Education Management,(Yogyakarta: ANDI, 2018). 
Schermerhorn. (2011). Organizational behaviour. Hoboken: Jhon Wiley and Sons. Semiawan, Conny R. Qualitative Research Methods. Grasindo, 2010.

Sudarwan Danim \& Suparno, Transformational Management and Leadership of The School Head,(Jakarta: PT RINEKA CIPTA, 2009).

Sugiyono. (2017). Qualitative, Quantitative and R\&D Research Methods [Qualitative, Quantitative and R\&D Research Methods]. Bandung: Alfabeta. Suti, M. (2011). Quality improvement strategies in the era of educational autonomy. Journal of Medtek Vol 3 No. 2.

Wahjusumidjo, Leadership Principal of the School of Theoretical Review and Its Problems. (Jakarta: PT. Rajagrafindo Persada, 2005).

Warsah, Idi, and Muhamad Uyun. "The Personality of educators: Study of Islamic Psychology." Psychic: Journal of Islamic Psychology 5, no. 1 (June 18, 2019): 62-73. https://doi.org/10.19109/Psikis.v5i1.3157.

Widoyoko, \& Putro. (2012). Research instrument preparation techniques. Yogyakarta: Learning Library.

Yuliharti \& Umiarso, Theoretical Construction in Islamic Education Management,(Jakarta: AMZAH, 2019).I

Yuniarsih, T. (2008). Human resource management. Bandung: Alfabeta. 